\title{
Product studies of gas-phase reactions of organic compounds
}

\author{
Roger Atkinson \\ Statewide Air Pollution Research Center, Department of Environmental Science, \\ and Department of Chemistry, University of California, Riverside, CA 92521, USA
}

\begin{abstract}
Large quantities of volatile non-methane organic compounds (NMOCs) are emitted into the atmosphere from anthropogenic and biogenic sources. In the troposphere, these NMOCs can undergo photolysis, reaction with the hydroxyl $(\mathrm{OH})$ radical, reaction with the nitrate $\left(\mathrm{NO}_{3}\right)$ radical, and reaction with ozone $\left(\mathrm{O}_{3}\right)$. While the kinetics of the initial $\mathrm{OH}$ radical, $\mathrm{NO}_{3}$ radical and $\mathrm{O}_{3}$ reactions are reasonably well known or can often be estimated with some degree of reliability, the subsequent reaction mechanisms and the products formed under tropospheric conditions are generally much less well understood. The various methods of generation of $\mathrm{OH}$ radicals, $\mathrm{NO}_{3}$ radicals and $\mathrm{O}_{3}$ for laboratory product studies, together with methods of analysis and potential complications due to other reactions, are discussed.
\end{abstract}

\section{INTRODUCTION}

Large quantities of volatile non-methane organic compounds (NMOCs) are emitted into the atmosphere from anthropogenic and biogenic sources, with the world-wide emissions being estimated to be 100 million tons per year from anthropogenic sources (ref. 1) and 1150 million tons per year from biogenic sources (ref. 2). In the troposphere in the gas phase, these NMOCs can undergo photolysis at wavelengths $>290 \mathrm{~nm}$, react with the hydroxyl $(\mathrm{OH})$ radical, react with the nitrate $\left(\mathrm{NO}_{3}\right)$ radical (primarily during nighttime hours), and react with ozone $\left(\mathrm{O}_{3}\right)$ (ref. 3,4). In addition, at certain times and locations reaction with the $\mathrm{Cl}$ atom can be important (ref. 5) and certain basic nitrogen-containing NMOCs (for example, amines) can react with gaseous nitric acid to form the corresponding nitrate salts (see, for example, ref. 6). As a result of some three decades of research, rate constants for the gas-phase reactions of a large number of NMOCs with $\mathrm{OH}$ radicals, $\mathrm{NO}_{3}$ radicals and $\mathrm{O}_{3}$ have been measured (ref. $3,7-10$ ), and methods (of varying reliablity depending on the structure of the NMOC) are available for the estimation of rate constants for NMOCs for which experimental data have not been obtained (ref. 7,9,11,12).

However, while the kinetics and mechanisms of the initial reactions of $\mathrm{OH}$ radicals, $\mathrm{NO}_{3}$ radicals and $\mathrm{O}_{3}$ with many NMOC are understood, the products and mechanisms of the subsequent reactions of the initially-formed radicals are much less well understood. A knowledge of the products and mechanisms of the tropospheric degradation reactions of NMOC is necessary to understand the impact of emissions of NMOC on the Earth's ecosystem, through effects such as deposition of NMOC reaction products (including of acidic species), in situ tropospheric formation of toxic air contaminants, the formation of photochemical air pollution on urban and regional scales, depletion of stratospheric ozone, and the potential for global warming.

The $\mathrm{OH}$ radical- and $\mathrm{NO}_{3}$ radical-initiated reactions of alkanes, alkenes and many other NMOCs lead to the formation of an alkyl or substituted alkyl radical ( $R$ ), which then reacts as shown schematically below (ref. 3,10 ) 


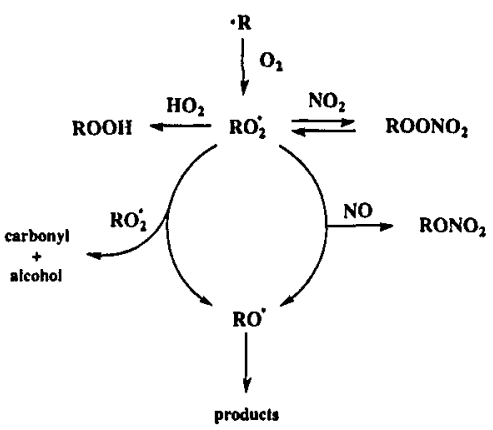

Reaction Scheme 1

The reactions of $\mathrm{O}_{3}$ with alkenes and NMOC containing $>\mathrm{C}=\mathrm{C}<$ bond(s) proceed by initial addition to form a primary ozonide, which then decomposes to a carbonyl plus a biradical (ref. 10):

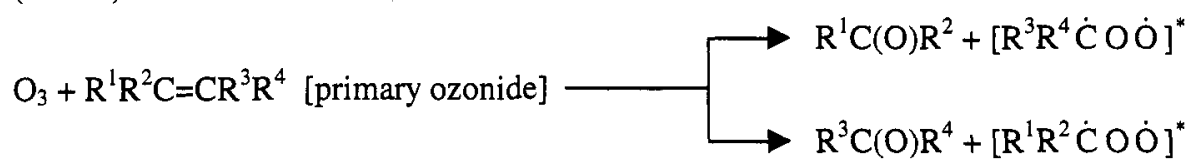

The initially energy-rich biradicals are then collisionally stabilized or react via decomposition/rearrangement pathways (ref. 10), as shown for the $\left[\left(\mathrm{CH}_{3}\right)_{2} \dot{\mathrm{C}} \mathrm{OO}\right]^{*}$ biradical,

$$
\begin{aligned}
& {\left[\left(\mathrm{CH}_{3}\right)_{2} \dot{\mathrm{COO}}\right]^{*}+\mathrm{M} \rightarrow\left(\mathrm{CH}_{3}\right)_{2} \dot{\mathrm{COOO}}+\mathrm{M}} \\
& {\left[\left(\mathrm{CH}_{3}\right)_{2} \dot{\mathrm{COO}}\right]^{*} \rightarrow\left[\mathrm{CH}_{3} \dot{\mathrm{C}}(\mathrm{O}) \mathrm{OCH}_{3}\right]^{*} \rightarrow \text { decomposition }} \\
& \text { (including to } \left.\mathrm{RH}+\mathrm{CO}_{2} \text { for the [R } \dot{\mathrm{C}} \mathrm{HOO}\right]^{*} \text { biradical) } \\
& {\left[\left(\mathrm{CH}_{3}\right)_{2} \dot{\mathrm{COO}}\right]^{*} \rightarrow\left[\mathrm{CH}_{3} \dot{\mathrm{C}}(\mathrm{OOH})=\mathrm{CH}_{2}\right]^{*} \rightarrow \mathrm{OH}+\mathrm{CH}_{3} \mathrm{C}(\mathrm{O}) \dot{\mathrm{C}} \mathrm{H}_{2}}
\end{aligned}
$$

followed by reactions of the stabilized biradicals and the other radical species formed from the decomposition/rearrangement reactions (these radicals often being alkyl or substituted alkyl radicals whose subsequent reactions are as shown in Reaction Scheme 1 above).

The other reaction system which differs from Reaction Scheme 1 concerns reaction of the $\mathrm{OH}$ radical with aromatic hydrocarbons, where a fraction (including all) of the reaction proceeds by initial $\mathrm{OH}$ radical addition to the carbon atoms of the aromatic ring to form a hydroxycyclohexadienyl radical [OH-aromatic adduct] (ref. 3,8). $\mathrm{OH}$-aromatic adducts then react with $\mathrm{O}_{2}$ and $\mathrm{NO}_{2}$, with the $\mathrm{O}_{2}$ reaction dominating for tropospheric conditions for the $\mathrm{OH}$-benzene, $\mathrm{OH}$-toluene and $\mathrm{OH}$-xylene adducts, but possibly not for $\mathrm{OH}$-polycyclic aromatic hydrocarbon (OH-PAH) adducts (ref. 3,13,14).

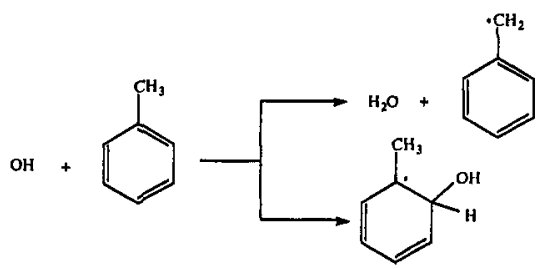

Reaction Scheme 2

There are two general approaches to studying the products of NMOC atmospheric reactions; one being to study the products and mechanisms of individual reactions involved in the NMOC atmospheric degradations; and the second to study the products of the $\mathrm{OH}$ radical, $\mathrm{NO}_{3}$ radical and $\mathrm{O}_{3}$ reactions of the NMOC of interest. A large amount of work has been 
carried out to investigate individual reactions involved in NMOC tropospheric degradations, examples being product studies of the self-reactions of $\mathrm{R} \dot{\mathrm{O}}_{2}$ radicals and of $\mathrm{R} \dot{\mathrm{O}}_{2}$ radicals with the $\mathrm{HO}_{2}$ radical, and studies of $\mathrm{CH}_{3} \mathrm{~S}$ and $\mathrm{CH}_{3} \mathrm{SO}$ radical reactions. As may be expected, extremely useful data are obtained from such studies and our knowledge of the mechanisms and products of $\mathrm{RO}_{2}+\mathrm{R} \dot{O}_{2}, \mathrm{RO}_{2}+\mathrm{HO}_{2}, \mathrm{CH}_{3} \mathrm{~S}$ and $\mathrm{CH}_{3}$ SO radical reactions arises from these studies (see ref. 15,16). The results of this type of study are evident in the NASA (ref. 17) and IUPAC (ref. 15,16) reviews and evaluations, as well as in the reviews and evaluations of NMOC chemistry of Atkinson (ref. 3,7-10). In fact, this is the best way to have a complete understanding of the elementary reactions involved in the tropospheric chemistry of an NMOC; however, the number of reactions to be studied, even for a single NMOC, is enormous and there are great difficulties in generating the intermediate radical species for such studies. Moreover, many of the studies of individual reactions are carried out at pressures and $\mathrm{O}_{2}$ concentrations very different from those encountered in the troposphere, and in some cases pressure and $\mathrm{O}_{2}$ dependencies are important, an example being the initial reaction of the $\mathrm{OH}$ radical with $\mathrm{CH}_{3} \mathrm{SCH}_{3}$ (ref. 16).

Despite the long-term advantages of studying individual elementary reactions, there is a place for studies of the products formed from the tropospheric oxidations of NMOCs, in which the first-generation products are identified and quantified and the reaction mechanism deduced from the product distribution. Such studies are the focus of this article (noting that many of the methods of $\mathrm{OH}$ radical and $\mathrm{NO}_{3}$ radical generation and product detection methods are also applicable to kinetic, product and mechanistic studies of elementary reactions). Only studies carried out at atmospheric pressure of air and at around room temperature are discussed.

\section{GENERATION OF OH RADICALS}

There are a number of methods used to generate $\mathrm{OH}$ radicals, with one of the criteria being the presence or absence of NO (which determines whether $\mathrm{R} \dot{\mathrm{O}}_{2}$ radicals react with NO or with $\mathrm{HO}_{2}$ and $\mathrm{R}_{2}$ radicals). The goal is to have a clean source of $\mathrm{OH}$ radicals with minimal complications caused by other reactive species such as $\mathrm{NO}_{3}$ radicals and $\mathrm{O}_{3}$ and by photolysis, and to have a sufficiently high concentration of $\mathrm{OH}$ radicals for sufficiently long that relatively low-reactivity NMOC can undergo appreciable reaction (i.e. $\int[\mathrm{OH}] \mathrm{t} \geq 1 \times 10^{12}$ molecule $\mathrm{cm}^{-3} \mathrm{~s}$ ). Not included here is the use of irradiated $\mathrm{NO}_{\mathrm{x}}-\mathrm{NMOC}$-air mixtures (ref. 18,19 ); these systems are not a clean source of $\mathrm{OH}$ radicals, with $\mathrm{NO}_{3}$ radicals and $\mathrm{O}_{3}$ typically being present at appreciable concentrations. Furthermore, the $\mathrm{OH}$ radical concentrations in irradiated $\mathrm{NO}_{\mathrm{x}}-\mathrm{NMOC}$-air mixtures are typically around $10^{6}$ molecule $\mathrm{cm}^{-3}$, and photolysis of the NMOC and/or of the reaction products can a complication.

Photolysis of HONO. Nitrous acid (HONO) photolyzes in the wavelength region $300-400 \mathrm{~nm}$ to form $\mathrm{OH}$ radicals (ref. 15),

$\mathrm{HONO}+\mathrm{h} v \rightarrow \mathrm{OH}+\mathrm{NO}$

and $\mathrm{OH}$ radical concentrations of $-5 \times 10^{7}$ molecule $\mathrm{cm}^{-3}$ can be readily obtained (ref. 20 ). In theory, the photolysis of $\mathrm{HONO}$ is an excellent source of $\mathrm{OH}$ radicals in the presence of $\mathrm{NO}$, because the overall reaction produces only $\mathrm{OH}$ radicals and NO. However, HONO must be sythesized prior to use and it is difficult to generate pure in the absence of significant quantities of $\mathrm{NO}$ and $\mathrm{NO}_{2}$ (ref. 20), which compete with the NMOC for $\mathrm{OH}$ radicals. This difficulty in reproducibly synthesizing pure HONO has been a factor in the relatively infrequent use of $\mathrm{HONO}$ as an $\mathrm{OH}$ radical precursor in product studies. The recently published preparation method of Febo et al. (ref. 21), involving the reaction of gaseous $\mathrm{HCl}$ with solid sodium nitrite,

$$
\mathrm{HCl}(\text { gas })+\mathrm{NaNO}_{3} \text { (solid) } \rightarrow \mathrm{NaCl}(\text { solid })+\mathrm{HONO}(\text { gas })
$$


to produce $>95 \%$ pure HONO should make HONO attractive as an $\mathrm{OH}$ radical precursor.

Photolysis of Alkyl Nitrites, RONO. The photolysis of alkyl nitrites of structure RRCHONO ( $\mathrm{R}, \hat{\mathrm{R}}=\mathrm{H}$ or alkyl) in the wavelength region $300-400 \mathrm{~nm}$ leads to the production of $\mathrm{OH}$ radicals through the reaction sequence.

$$
\begin{aligned}
& \mathrm{RRCHONO}+\mathrm{h} v \rightarrow \mathrm{RRCHO}+\mathrm{NO} \\
& \mathrm{RRCHO}+\mathrm{O}_{2} \rightarrow \mathrm{RC}(\mathrm{O}) \dot{\mathrm{R}}+\mathrm{HO}_{2} \\
& \mathrm{HO}_{2}+\mathrm{NO} \rightarrow \mathrm{OH}+\mathrm{NO}_{2}
\end{aligned}
$$

Using methyl nitrite photolysis, $\mathrm{OH}$ radical concentrations of $\sim 1 \times 10^{8}$ molecule $\mathrm{cm}^{-3}$ can be readily obtained for time-scales of $10 \mathrm{~min}$ or more (the time being limited by the photolytic lifetime of methyl nitrite) (ref. 22). The advantage of alkyl nitrites as an $\mathrm{OH}$ radical precursor is that the alkyl nitrites are easy to synthesize in pure form and can be readily stored for indefinite periods of time. The disadvantage is that the overall reaction

$$
\mathrm{RR} C H O N O+h v \quad\left(+\mathrm{O}_{2}\right) \rightarrow \mathrm{OH}+\mathrm{RC}(\mathrm{O}) \dot{\mathrm{R}}+\mathrm{NO}_{2}
$$

leads to the co-production of $\mathrm{NO}_{2}$, which is both a sink for $\mathrm{OH}$ radicals (through its reaction to form nitric acid) and a source of $\mathrm{O}_{3}$ and hence $\mathrm{NO}_{3}$ radicals, through the reactions.

$$
\begin{aligned}
& \mathrm{NO}_{2}+\mathrm{h} v \rightarrow \mathrm{NO}+\mathrm{O}\left({ }^{3} \mathrm{P}\right) \\
& \mathrm{O}\left({ }^{3} \mathrm{P}\right)+\mathrm{O}_{2}+\mathrm{M} \rightarrow \mathrm{O}_{3}+\mathrm{M} \\
& \mathrm{NO}_{2}+\mathrm{O}_{3} \rightarrow \mathrm{NO}_{3}+\mathrm{O}_{2}
\end{aligned}
$$

Furthermore, the formation of a carbonyl (HCHO from methyl nitrite, $\mathrm{CH}_{3} \mathrm{CHO}$ from ethyl nitrite, acetone from isopropyl nitrite and 2-butanone from 2-butyl nitrite) can interfere with the analysis of products from the NMOC being studied (for example, the use of methyl nitrite precludes the analysis of $\mathrm{HCHO}$ as a product of the NMOC being studied). Precautions need to be taken to minimize or avoid, or take into account, the possible reactions of the organic being studied with $\mathrm{O}\left({ }^{3} \mathrm{P}\right)$ atoms [from photolysis of $\mathrm{NO}_{2}$; reaction (9)], $\mathrm{O}_{3}$, and $\mathrm{NO}_{3}$ radicals. Inclusion of NO in the reactant mixtures (i.e., RONO-NO-NMOC-air mixtures) is generally used to suppress the formation of $\mathrm{O}_{3}$ and hence of $\mathrm{NO}_{3}$ radicals by the reaction

$\mathrm{NO}+\mathrm{O}_{3} \rightarrow \mathrm{NO}_{2}+\mathrm{O}_{2}$

The photolysis of alkyl nitrites has been widely used to generate $\mathrm{OH}$ radicals in kinetic and product studies, with examples in product studies being the use of methyl nitrite (ref. 23), ethyl nitrite (ref. 24,25), isopropyl nitrite (ref. 26) and 2-butyl nitrite (ref. 24).

Other $\mathrm{OH}$ Radical Sources (in the Presence of $N \mathrm{O}_{x}$ ). Other sources of $\mathrm{OH}$ radicals in the presence of $\mathrm{NO}_{\mathrm{x}}$ have been utilized for kinetic studies (ref. 8), these being the dark reaction of $\mathrm{HO}_{2} \mathrm{NO}_{2}$ (pernitric acid) with $\mathrm{NO}$ (ref. 27),

$$
\begin{aligned}
& \mathrm{HO}_{2} \mathrm{NO}_{2} \rightleftharpoons \mathrm{HO}_{2}+\mathrm{NO}_{2} \\
& \mathrm{HO}_{2}+\mathrm{NO} \rightarrow \mathrm{OH}+\mathrm{NO}_{2}
\end{aligned}
$$

the dark reaction of hydrazine and $\mathrm{O}_{3}$ (ref. 28),

$\mathrm{O}_{3}+\mathrm{N}_{2} \mathrm{H}_{4} \rightarrow \mathrm{OH}+$ products (possibly including $\mathrm{NO}_{\mathrm{x}}$ ) 
and the dark, heterogeneous reaction of hydrogen peroxide with $\mathrm{NO}_{2}$ (ref. 29). The use of dark reactions to generate $\mathrm{OH}$ radicals has the advantage of avoiding the possibility of photolysis of the NMOC reactant and/or reaction products. However, the presence of $\mathrm{O}_{3}$ in the $\mathrm{O}_{3}+\mathrm{N}_{2} \mathrm{H}_{4}$ system precludes studies of NMOC which react with $\mathrm{O}_{3}$, and the $\mathrm{O}_{3}+\mathrm{N}_{2} \mathrm{H}_{4}$ and the $\mathrm{H}_{2} \mathrm{O}_{2}+\mathrm{NO}_{2}$ reaction systems are complex and incompletely understood, and are presently probably not appropriate for use in product studies.

A few methods of generation of $\mathrm{OH}$ radicals in the absence of $\mathrm{NO}_{\mathrm{x}}$ have been used for product studies, as noted below.

Photolysis of $\mathrm{H}_{2} \mathrm{O}_{2}$. The photolysis of $\mathrm{H}_{2} \mathrm{O}_{2}$ at wavelengths $<300 \mathrm{~nm}$ (for example, at 254 $\mathrm{nm}$ ) leads to the formation of $\mathrm{OH}$ radicals (ref. 15).

$\mathrm{H}_{2} \mathrm{O}_{2}+\mathrm{h} v \rightarrow 2 \mathrm{OH}$

Obviously, the photolysis of $\mathrm{H}_{2} \mathrm{O}_{2}-\mathrm{NO}-\mathrm{NMOC}$-air mixtures will lead to the generation of $\mathrm{OH}$ radicals in the presence of $\mathrm{NO} . \mathrm{H}_{2} \mathrm{O}_{2}$ is a "sticky" compound, with a strong potential for loss to reaction vessel walls where it may participate in heterogeneous reactions. Furthermore, the necessity to use wavelengths $<300 \mathrm{~nm}$ also leads to the potential for photolysis of the NMOC and/or reaction products.

Dark Reaction of $\mathrm{O}_{3}$ with Alkenes. The observations that the gas-phase reactions of $\mathrm{O}_{3}$ with alkenes and other NMOC containing $>\mathrm{C}=\mathrm{C}<$ bonds lead to the production of $\mathrm{OH}$ radicals [reaction (2c)], often in close to unit yield (ref. 30-33), has led to the use of this reaction system as a dark source of $\mathrm{OH}$ radicals in the absence of NO (ref. 13,34,35). This source of $\mathrm{OH}$ radicals has decided limitations; to NMOCs which do not react with $\mathrm{O}_{3}$ (ref. 13,34) or to the alkene or NMOC containing a $>\mathrm{C}=\mathrm{C}<$ bond whose reaction with $\mathrm{O}_{3}$ is being used as the $\mathrm{OH}$ radical source (ref. 35). Furthermore, the competition between the NMOC being studied and the alkene (or compound containing the $>\mathrm{C}=\mathrm{C}<$ bond) for $\mathrm{OH}$ radicals limits the amount of reaction of the NMOC being studied. Atkinson and Aschmann (ref. 13), using part-permillion mixing ratios of alkene and aromatic hydrocarbon (the NMOC being studied), obtained up to $-30 \%$ reaction for an NMOC with a relatively high $\mathrm{OH}$ radical reaction rate constant of $-3.5 \times 10^{-11} \mathrm{~cm}^{3}$ molecule $\mathrm{e}^{-1} \mathrm{~s}^{-1}$.

\section{GENERATION OF $\mathrm{NO}_{3}$ RADICALS.}

Two methods have been used to generate $\mathrm{NO}_{3}$ radicals in product studies carried out at atmospheric pressure, as discussed below.

Thermal Decomposition of $\mathrm{N}_{2} \mathrm{O}_{5}$. The thermal decomposition of $\mathrm{N}_{2} \mathrm{O}_{5}$ (ref. 15)

$\mathrm{N}_{2} \mathrm{O}_{5} \rightarrow \mathrm{NO}_{3}+\mathrm{NO}_{2}$

leads to the generation of $\mathrm{NO}_{3}$ radicals, and this radical generation method has been extensively used for product studies (ref. 36,37). $\mathrm{N}_{2} \mathrm{O}_{5}$ is readily synthesized from the reaction of $\mathrm{NO}_{2}$ with $\mathrm{O}_{3}$ [reaction (11)] followed by,

$\mathrm{NO}_{3}+\mathrm{NO}_{2} \rightleftarrows \mathrm{N}_{2} \mathrm{O}_{5}$

with $\mathrm{N}_{2} \mathrm{O}_{5}$ being collected in a trap cooled to $196 \mathrm{~K} . \mathrm{N}_{2} \mathrm{O}_{5}$ can be stored indefinitely at $77 \mathrm{~K}$ under vacuum.

In Situ Generation of $\mathrm{NO}_{3}$ Radicals (and $\mathrm{N}_{2} \mathrm{O}_{5}$ ). Reaction of $\mathrm{O}_{3}$ with $\mathrm{NO}_{2}$ leading to $\mathrm{NO}_{3}$ radical formation [reaction (11)], followed by reactions $(16)$ and $(-16)$ has been used to generate $\mathrm{NO}_{3}$ radicals in situ in the reaction vessel for product studies (ref. 37). 


\section{GENERATION OF $\mathrm{O}_{3}$}

$\mathrm{O}_{3}$ is readily produced by either a corona discharge in $\mathrm{O}_{2}$ using commercial ozone generators, or by photolysis of $\mathrm{O}_{2}$ or air at $184.9 \mathrm{~nm}$ using commercial low-pressure mercury arcs with a quartz envelope, and no further discussion is given here.

\section{REACTION VESSELS}

A variety of reaction vessels have been used for product studies, with static reaction vessels ranging in volume from $<1$ to $\sim 150,000$ liter (ref. 38,39). In static [or slow-flow systems which are effectively continuous stirred-flow reaction vessels (ref. 40)], NMOC reactants are exposed to $\mathrm{OH}$ radicals, $\mathrm{NO}_{3}$ radicals or $\mathrm{O}_{3}$, and products are analyzed by whatever analytical method is appropriate (and works). High pressure flow systems have been used in a few studies: Berndt and Böge (ref. 41) have used a flow system capable of operation over the pressure range $-5-1000$ mbar to study $\mathrm{NO}_{3}$ radical reactions, producing $\mathrm{NO}_{3}$ radicals by the thermal decomposition of $\mathrm{N}_{2} \mathrm{O}_{5}$ and analyzing the reactants and reaction products by gas chromatographic methods; and Donahue et al. (ref. 42) have used a high pressure flow system with a modulated $\mathrm{OH}$ radical source to investigate the products of the reaction of the $\mathrm{OH}$ radical with $\mathrm{CF}_{3} \mathrm{CF}=\mathrm{CF}_{2}$ in the presence of $\mathrm{NO}$, with analysis by in situ Fourier transform infrared (FTIR) absorption spectroscopy.

\section{ANALYTICAL TECHNIQUES}

As expected, a number of analytical methods have been used for the identification and quantification of reactants and reaction products. These include in situ FTIR absorption spectroscopy, in situ mass spectrometry (MS), in situ atmospheric pressure ionization tandem mass spectrometry (API-MS/MS), and (generally off-line) analyses by gas chromatography with flame ionization detection (GC-FID), gas chromatography with FTIR detection (GCFTIR), combined gas chromatography-mass spectrometry (GC-MS and GC-MS/MS), and various derivatization-chromatography methods (including high performance liquid chromatography with various detectors). All of these analytical methods have their advantages and disadvantages, and the various analytical techniques tend to be complementary. For example, many hydroxycarbonyl compounds do not gas chromatograph without derivatization (which is also neither simple not necessarily quantitative), and FTIR absorption spectroscopy often loses many of its advantages when dealing with relatively large $\left(>\mathrm{C}_{5}\right)$ oxygenated organic compounds because of the similarity of group absorptions irrespective of the isomeric structure of the compound (and hence the potential for overlapping absorption bands and nonspecificity in compound identification). API-MS/MS has proven useful for the identification of multifunctional oxygenated products species such as hydroxycarbonyls, hydroxyhydroperoxides, carbonyl-hydroperoxides, nitrooxycarbonyls and nitrooxyhydroperoxides (ref. 43,44), although to date the identifications have not been isomer specific. GC techniques have good sensitivity and when coupled with MS and, to a lesser extent, FTIR detectors, provide good identification capabilities. However, the requirement to be able to chromatograph a compound can cause difficulties (for example, for many hydroxycarbonyls and hydroperoxides). The use of gas sampling loops and injection valves lead to problems for $>\mathrm{C}_{10}$ hydrocarbons and oxygenated compounds with less carbon atoms; these problems can be circumvented by sample collection onto solid adsorbents with subsequent thermal desorption directly (with cryofocusing) onto a GC column (ref. 31,35 ). FTIR spectroscopy is generally less sensitive than GC analyses, therefore requiring higher initial reactant concentrations which can conflict with a desire to use low initial reactant concentrations for low volatility NMOC (to minimize wall adsorption/desorption problems on the reaction vessel walls). Combined with a general lack of compound identification 
specificity for larger NMOC, FTIR spectroscopy is best suited to the analyses of products formed from relatively small $\left(\leq \mathrm{C}_{6}\right)$ NMOC [a prime example being for the products of the tropospheric degradation reactions of hydrofluorocarbons and hydrochlorofluorocarbons (ref. $45,46)]$.

Various experimental methods used in product studies of the reactions of $\mathrm{OH}$ radicals, $\mathrm{NO}_{3}$ radicals and $\mathrm{O}_{3}$ with $\mathrm{NMOC}$ are described in ref. 35,39,43,44,47-51 and these publications should be consulted for further details. In particular, the use of several analytical techniques to study the same reaction system allows for a more comprehensive product identification and quantification, with data for certain products being obtained by more than one analysis method.

\section{POSSIBLE EXPERIMENTAL COMPLICATIONS}

Besides the need to be aware of the potential for reactions of the NMOC with $\mathrm{O}\left({ }^{3} \mathrm{P}\right)$ atoms, $\mathrm{O}_{3}$, and $\mathrm{NO}_{3}$ radicals when using the photolysis of nitrous acid or alkyl nitrites as a source of $\mathrm{OH}$ radicals (see, for example, ref. 52), there are other complications for certain NMOC, as noted below.

Reactions of $\mathrm{NMOC}$ with $\mathrm{NO}_{2}$. A number of alkenes (mainly conjugated dienes) react with $\mathrm{NO}_{2}$ in the gas phase (ref. 10 and references therein). A partial listing of the alkenes which react with $\mathrm{NO}_{2}$ and their room temperature rate constants is given in ref. 10, and the rate constants for those NMOC which are observed to react with $\mathrm{NO}_{2}$ range up to $1.3 \times 10^{-17} \mathrm{~cm}^{3}$ molecule $\mathrm{e}^{-1} \mathrm{~s}^{-1}$. For an $\mathrm{NO}_{2}$ concentration of $1 \times 10^{13}$ molecule $\mathrm{cm}^{-3}$ (a mixing ratio of $\sim 400$ $\mathrm{ppb}$ ), this results in up to $0.8 \% \mathrm{~min}^{-1}$ reaction of the NMOC, a complication which cannot be ignored in laboratory studies. Moreover, in the presence of $\mathrm{NO}$ in air, the products of the $\mathrm{NO}_{2}$ reaction lead to the formation of $\mathrm{OH}$ radicals (ref. 10), and the dark losses of the NMOC are then due to reaction with $\mathrm{NO}_{2}$ and $\mathrm{OH}$ radicals and the consumption rate of the NMOC is around twice as fast as expected from the $\mathrm{NO}_{2}$ reaction alone. Indeed, for NMOC such as phellandrene and -terpinene, dark $\mathrm{NO}-\mathrm{NO}_{2}$-alkene-air mixtures can be used to study the products of the $\mathrm{OH}$ radical reactions (after taking into account the products formed from the $\mathrm{NO}_{2}$ reaction).

Formation of $\mathrm{OH}$ Radicals from the $\mathrm{O}_{3}$ Reactions with $\mathrm{NMOC}$. The finding that $\mathrm{OH}$ radicals are formed, often in close to unit yield, from the reactions of $\mathrm{O}_{3}$ with alkenes and other NMOC containing $>\mathrm{C}=\mathrm{C}<$ bonds (ref. 30-33) means that unless the $\mathrm{OH}$ radicals are scavenged the reaction being studied involves both $\mathrm{OH}$ radical and $\mathrm{O}_{3}$ reactions and the products observed and quantified are not solely from the $\mathrm{O}_{3}$ reaction. Product studies of $\mathrm{O}_{3}$ reactions over the past 8 years have used sufficient concentrations of an alkane (for example, cyclohexane) to scavenge $>90-95 \%$ of the $\mathrm{OH}$ radicals formed from the $\mathrm{O}_{3}$ reaction (ref. $47,50,53)$.

Formation of $\mathrm{Cl}$ Atoms from Chlorine-Containing NMOC. The reactions of $\mathrm{OH}$ radicals, $\mathrm{NO}_{3}$ radicals and $\mathrm{O}_{3}$ with chlorine-containing NMOCs have the potential to lead to the formation of $\mathrm{Cl}$ atoms, which are highly reactive towards most NMOC and can initiate chain reactions (ref. 54). Again, a sufficient concentration of an alkane can be added to the reactant mixture to scavenge the majority of any $\mathrm{Cl}$ atoms formed. Ethane has often been used as the alkane because it rapidly with $\mathrm{Cl}$ atoms but is of low reactivity towards both $\mathrm{OH}$ radicals and $\mathrm{NO}_{3}$ radicals (ref. 16).

Reactions of NMOC with Gaseous Nitric Acid. A number of amines and other nitrogencontaining NMOC react with gaseous nitric acid to form the nitrate salts.

$\left(\mathrm{CH}_{3}\right)_{2} \mathrm{NH}+\mathrm{HNO}_{3} \rightarrow\left[\left(\mathrm{CH}_{3}\right)_{2} \mathrm{NH}_{2}\right]^{+} \mathrm{NO}_{3}^{-}$ 
Because nitric acid is formed when generating $\mathrm{OH}$ radicals in the presence of $\mathrm{NO}$ (from the $\mathrm{OH}+\mathrm{NO}_{2}$ reaction) and from wall losses of $\mathrm{N}_{2} \mathrm{O}_{5}$, studies of the $\mathrm{OH}$ radical and $\mathrm{NO}_{3}$ radical reactions with certain nitrogen-containing NMOC can be complicated by additional losses of the NMOC due to reaction with gaseous nitric acid generated during the reactions. Tuazon $e t$ al. (ref. 55) circumvented this problem by scavenging nitric acid during the $\mathrm{OH}$ radicalinitiated reaction of 2-vinylpyridine, by adding excess pyridine to the reactant mixtures.

\section{CONCLUSIONS}

While much progress has been made during the past few years (see, for example, ref. 47-51), product studies are still limited by the need for better analytical techniques for the identification and quantification of oxygenated product species, and by the general lack of commercially available standards for identification and quantification purposes.

\section{REFERENCES}

1. World Meteorological Organization, Scientific Assessment of Ozone Depletion: 1994. World Meteorological Organization Global Ozone Research and Monitoring Project Report No. 37, Geneva, Switzerland (1995).

2. A. Guenther, C.N. Hewitt, D. Erickson, R. Fall, C. Geron, T. Graedel, P. Harley, L. Klinger, M. Lerdau, W.A. McKay, T. Pierce, B. Scholes, R. Steinbrecher, R. Tallamraju, J. Taylor, P. Zimmermann. J. Geophys. Res. 100, 8873-8892 (1995).

3. R. Atkinson. J. Phys. Chem. Ref. Data Monograph 2, 1-216 (1994).

4. R. Atkinson. In Volatile Organic Compounds in the Atmosphere, Issues in Environmental Science and Technology 4, 65-89 (1995).

5. B.T. Jobson, H. Niki, Y. Yokouchi, J. Bottenheim, F. Hopper, R. Leaitch. J. Geophys. Res. 99, 25355-25368 (1994).

6. R. Atkinson, E.C. Tuazon, T.J. Wallington, S.M. Aschmann, J. Arey, A.M. Winer, J.N. Pitts, Jr. Environ. Sci. Technol. 21, 64-72 (1987).

7. R. Atkinson, W.P.L. Carter. Chem. Rev. 84, 437-470 (1984).

8. R. Atkinson. J. Phys. Chem. Ref. Data Monograph 1, 1-246 (1989).

9. R. Atkinson. J. Phys. Chem. Ref. Data 20, 459-507 (1991).

10. R. Atkinson. J. Phys. Chem. Ref. Data 26, 215-290 (1997).

11. E.S.C. Kwok, R. Atkinson. Atmos. Environ. 29, 1685-1695 (1995).

12. Atmospheric Oxidation Program, Version 1.8, Syracuse Research Corporation, Syracuse, NY (1997).

13. R. Atkinson, S.M. Aschmann. Int. J. Chem. Kinet. 26, 929-944 (1994).

14. R. Atkinson, J. Arey. Environ. Health Perspect. 102(Suppl. 4), 117-126 (1994).

15. R. Atkinson, D.L. Baulch, R.A. Cox, R.F. Hampson, Jr., J.A. Kerr, M.J. Rossi, J. Troe. J. Phys. Chem. Ref. Data 26, 1329-1499 (1997).

16. R. Atkinson, D.L. Baulch, R.A. Cox, R.F. Hampson, Jr., J.A. Kerr, M.J. Rossi, J. Troe. J. Phys. Chem. Ref. Data submitted for publication (1998).

17. W.B. DeMore, S.P. Sander, D.M. Golden, R.F. Hampson, M.J. Kurylo, C.J. Howard, A.R. Ravishankara, C.E. Kolb, M.J. Molina. Chemical Kinetics and Photochemical Data for use in Stratospheric Modeling, NASA Panel for Data Evaluation, Evaluation No. 12, Jet Propulsion Laboratory Publication 97-4, January 15, 1997.

18. G.J. Doyle, A.C. Lloyd, K.R. Darnall, A.M. Winer, J.N. Pitts, Jr. Environ. Sci. Technol. 9, 237-241 (1975).

19. A. Maldotti, C. Chiorboli, C.A. Bignozzi, C. Bartocci, V. Carassiti. Int. J. Chem. Kinet. 12, 905-913 (1980).

20. H. Niki, P.D. Maker, C.M. Savage, L.P. Breitenbach. J. Phys. Chem. 82, 135-137 (1978). 
21. A. Febo, C. Perrino, M. Gherardi, R. Sparapani. Environ. Sci. Technol. 29, 2390-2395 (1995).

22. R. Atkinson, W.P.L. Carter, A.M. Winer, J.N. Pitts, Jr. J. Air Pollut. Control Assoc. 31, 1090-1092 (1981).

23. R. Atkinson, S.M. Aschmann, W.P.L. Carter, A.M. Winer, J.N. Pitts, Jr. J. Phys. Chem. 86, 4563-4569 (1982).

24. H. Niki, P.D. Maker, C.M. Savage, L.P. Breitenbach. Chem. Phys. Lett. 80, 499-503 (1981).

25. E.C. Tuazon, R. Atkinson. Int. J. Chem. Kinet. 22, 1221-1236 (1990).

26. N.J. Bunce, L. Liu, J. Zhu, D.A. Lane. Environ. Sci. Technol. 31, 2252-2259 (1997).

27. I. Barnes, V. Bastian, K.H. Becker, E.H. Fink, F. Zabel. Atmos. Environ. 16, 545-550 (1982).

28. E.C. Tuazon, W.P.L. Carter, R. Atkinson, J.N. Pitts, Jr. Int. J. Chem. Kinet. 15, 619629 (1983).

29. I.M. Campbell, D.F. McLaughlin, B.J. Handy. Chem. Phys. Lett. 38, 362-364 (1976).

30. S.E. Paulson, R.C. Flagan, J.H. Seinfeld. Int. J. Chem. Kinet. 24, 103-125 (1992).

31. R. Atkinson, S.M. Aschmann, J. Arey, B. Shorees. J. Geophys. Res. 97, 6065-6073 (1992).

32. S.E. Paulson, A.D. Sen, P. Liu, J.D. Fenske, M.J. Fox. Geophys. Res. Lett. 24, $3193-$ 3196 (1997).

33. N.M. Donahue, J.H. Kroll, J.G. Anderson, K.L. Demerjian. Geophys. Res. Lett. 25, 59-62 (1998).

34. E.S.C. Kwok, S.M. Aschmann, R. Atkinson, J. Arey. J. Chem. Soc. Faraday Trans. 93, 2847-2854 (1997).

35. E.C. Tuazon, S.M. Aschmann, J. Arey, R. Atkinson. Environ. Sci. Technol. submitted for publication (1998).

36. J. Arey, B. Zielinska, R. Atkinson, S.M. Aschmann. Int. J. Chem. Kinet. 21, 775-799 (1989).

37. H. Skov, J. Hjorth, C. Lohse, N.R. Jensen, G. Restelli. Atmos. Environ. 26A, 27712783 (1992).

38. J.F. Meagher and J. Heicklen. J. Phys. Chem. 80, 1645-1652 (1976).

39. J. Yu, H.E. Jeffries, R.M. Lacheur. Environ. Sci. Technol. 29, 1923-1932 (1995).

40. M.W. Gery, D.L. Fox, R.M. Kamens, L. Stockburger. Environ. Sci. Technol. 21, 339348 (1987).

41. T. Berndt, O. Böge. Ber. Bunsenges. Phys. Chem. 98, 869-871 (1994).

42. N.M. Donahue, K.L. Demerjian, J.G. Anderson. J. Geophys. Res. 100, 17855-17861 (1996).

43. E.S.C. Kwok, S.M. Aschmann, J. Arey, R. Atkinson. Int. J. Chem. Kinet. 28, 925-934 (1996).

44. S.M. Aschmann, A.A. Chew, J. Arey, R. Atkinson. J. Chem. Phys. A 101, 8042-8048 (1997).

45. T.J. Wallington, M.D. Hurley, J.C. Ball, E.W. Kaiser. Environ. Sci. Technol. 26, 1318-1324 (1992).

46. E.C. Tuazon, R. Atkinson. J. Atmos. Chem. 16, 301-312 (1993).

47. Y. Shu, E.S.C. Kwok, E.C. Tuazon, R. Atkinson, J. Arey. Environ. Sci. Technol. 31, 896-904 (1997).

48. J. Yu, H.E. Jeffries, K.G. Sexton. Atmos. Environ. 31, 2261-2280 (1997).

49. J. Yu, H.E. Jeffries. Atmos. Environ. 31, 2281-2287 (1997).

50. S.M. Aschmann, Y. Shu, J. Arey, R. Atkinson. Atmos. Environ. 31, 3551-3560 (1997).

51. I. Wängberg, I. Barnes, K.H. Becker. Environ. Sci. Technol. 31, 2130-2135 (1997).

52. S.E. Paulson, R.C. Flagan, J.H. Seinfeld. Int. J. Chem. Kinet. 24, 79-101 (1992).

53. H. Hakola, J. Arey, S.M. Aschmann, R. Atkinson. J. Atmos. Chem. 18, 75-102 (1994).

54. E.C. Tuazon, R. Atkinson, S.M. Aschmann, M.A. Goodman, A.M. Winer. Int. J. Chem. Kinet. 20, 241-265 (1988).

55. E.C. Tuazon, J. Arey, R. Atkinson, S.M. Aschmann. Environ. Sci. Technol. 27, 18321841 (1993). 